\section{Origin of Walnut Somatic Embryos Determined by RFLP and Isozyme Analysis}

\author{
Mohammed A.M. Aly, Robert G. Fjellstrom, Gale H. McGranahan, \\ and Dan E. Parfitt \\ Department of Pomology, University of California, Davis, CA 95616
}

Additional index words. Juglans regia, molecular markers, apomixis, phosphoglucomutase, restriction fragment length polymorphism

\begin{abstract}
Somatic embryos derived from walnut (Juglans regia L.) ovule tissues were evaluated to determine whether they were of zygotic or maternal origin. Molecular markers were used to permit evaluation at an early stage, before whole plant development. Somatic embryos developed from potentially apomictic 'Sunland' and 'Cisco' ovule tissue isolated from bagged putatively unpollinated flowers. Phosphoglucomutase (PGM) isozyme analysis showed that all of these embryos, except one from each cultivar, carry the same zymotype as the maternal tissue. However, restriction fragment length polymorphism (RPLP) analysis combined with isozyme evaluation demonstrated that the tested embryos originated from zygotic rather than maternal tissues. This study demonstrates the application of molecular marker analyses, particularly RFLPs, evaluation of somatic embryo origin.
\end{abstract}

Commercially important walnut cultivars may be improved by adding traits such as disease and pest resistance to their genetic makeup: Incorporation of novel genes by genetic transformation can complement conventional breeding, but plant regeneration from genetically manipulated cells is a prerequisite to this approach. In walnut, repetitively embryogenic somatic embryos have been used as the target tissue for genetic transformation and regeneration of transgenic plants (McGranahan et al., 1988,1990). However, somatic embryo cultures have only been obtained from immature walnut embryo tissues (Tulecke and McGranahan, 1985) and from endosperm (Tulecke et al., 1988), but not from clonal (nonzygotic) tissues of commercially desirable cultivars. Use of clonal (vegetative) tissues as a source of somatic embryos is advantageous to avoid meiosis and genetic recombination and produce plants that are identical to the parents except for the introduced genes.

The origin of somatic embryos can be determined from histological analysis of the embryos and associated tissues, karyotype, and/or morphological analysis in many crops. Histological methods result in destruction of the embryo. Karyotype analysis is limited to detection of gross chromosomal differences

Received for publication 17 Dec. 1990. This paper was supported in part by the California Walnut Marketing Board. We wish to acknowledge the advice and assistance of C.A. Leslie, S. Arulsekar, and Y. Gogorcena. Mention of a product or trade name does not imply endorsement or recommendation of the product or the exclusion of others that may be suitable. The cost of publishing this paper was defrayed in part by the payment of page charges. Under postal regulations, this paper therefore must be hereby marked advertisement solely to indicate this fact.

${ }^{1}$ Present address: Div. of Genetic Engineering, National Research Center, Giza, Egypt. and is not feasible in walnut due to small chromosome size (Woodworth, 1930). Morphological analysis, especially of fruit or flower, is prolonged due to the long generation time of walnut. Analysis using molecular genetic markers is an alternative that can be instrumental for rapidly determining the parentage of plants regenerated in vitro. Protein markers have proven their utility in ascertaining the genotypic parentage of tissue culture-derived plants (Zamir et al., 1981). The detection of restriction fragment length polymorphisms (RFLP) by single copy or cDNA probes has allowed diagnostic identification of strains of fungi (Castle et al., 1987). DNA "fingerprints" have been used to differentiate among rice (Oryza sativa $\mathrm{L}$.) cultivars (Dallas, 1988) and several other plant species (Rogstad et al., 1988). RFLP is potentially useful for determining the parental nature of tissue-culture regenerants, particularly in Juglans regia, where only two polymorphic isozyme markers are available (Arulsekar et al., 1986).

This paper demonstrates the application of molecular markers to ascertain the origin of some walnut somatic embryos that resulted from a study to induce somatic embryos from somatic or apomictic tissues of commercial walnut cultivars. Isozyme and RFLP analyses were used for early determination of the parentage of somatic embryos.

Embryo culture. Su1-Su3 and Ci1-Ci4 somatic embryos were obtained from immature female flowers of 'Sunland' and 'Cisco', respectively. The flowers were enclosed in polyester nonwoven pollination bags in May 1990 to exclude pollen, before they reached the receptive stage. Three weeks after anthesis, fruits were collected, dissected immediately, or stored in plastic bags at $4 \mathrm{C}$ for up to 30 days before dissection.

Fruits were washed with detergent, rinsed with distilled water, immersed in $70 \%$ ethanol for $10 \mathrm{sec}$, and placed in a stirred $0.1 \%$ sodium hypochlorite solution (2\% commercial bleach), pH 8 (Sauer and Burroughs, 1986) for $5 \mathrm{~min}$, rinsed three times in sterilized distilled water, blotted on sterile filter paper, and placed on slightly moistened filter paper to prevent desiccation during dissection.

Two 'Sunland' ovules were aseptically removed and cultured, one per petri dish, on DKW-C basal medium (McGranahan et al., 1988), supplemented with $1.7 \mathrm{~mm}$ glutamine, $4.6 \mu \mathrm{m}$ zeatin, $0.45 \mu \mathrm{m}$ thidiazuron (TDZ), $17.0 \mu \mathrm{M}$ indole-3-acetic acid (IAA), and solidified with $0.5 \%$ Seaplaque agarose (FMC, Rockland, Maine), pH 5.7. The dishes were individually wrapped with parafilm and incubated at 25C in darkness or under a 16$\mathrm{h}$ photoperiod under cool-white fluorescent lamps at $87 \mu \mathrm{mol} \cdot \mathrm{m}^{-2} \mathrm{~s}^{-1}$.

The 'Sunland' ovules did not develop past an initial nucellus expansion. After 8 weeks, the nucellus tissue was cut open and examined microscopically to determine whether or not it contained differentiating tissues. These ovules contained white, solid, spherical masses of interior tissues (suspected embryos) after 10 weeks of culture. These masses (Su2 and $\mathrm{Su} 3)$ were isolated from the ovules and cultured separately on DKW-C basal medium, supplemented with $1.7 \mathrm{mM}$ glutamine, $0.05 \mu \mathrm{M}$ TDZ, $5.7 \mu \mathrm{M}$ IAA, $10 \mu \mathrm{M}$ silver nitrate, Cefotaxime (500 mg.liter ${ }^{-1}$ ), and solidified with $0.24 \%$ Gelrite (Merck, Rawhay, N.J.), pH 5.7. In addition, a torpedo-shaped somatic embryo (Su1) was found on the underside of the Su2 ovule. The site of origin of this torpedo stage embryo on the

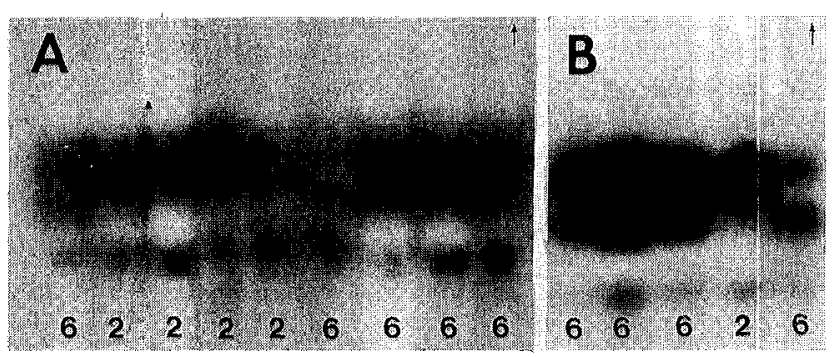

Fig. 1. PGM-1 zymotypes of the somatic embryos and their maternal parents. Band patterns 2 and 6 are shown. Arrows indicate direction of runs. (A) Lanes $1-4=\mathrm{Ci1}-\mathrm{Ci} 4$, lane $5=$ 'Cisco' (maternal genotype), lane $6=$ 'Sunland' (maternal genotype), lanes 7-9 = Su1-Su3. (B) Lane $1=$ 'Sunland', lanes $2-5=$ 'Sunland' somatic embryos from open pollinated flowers. 


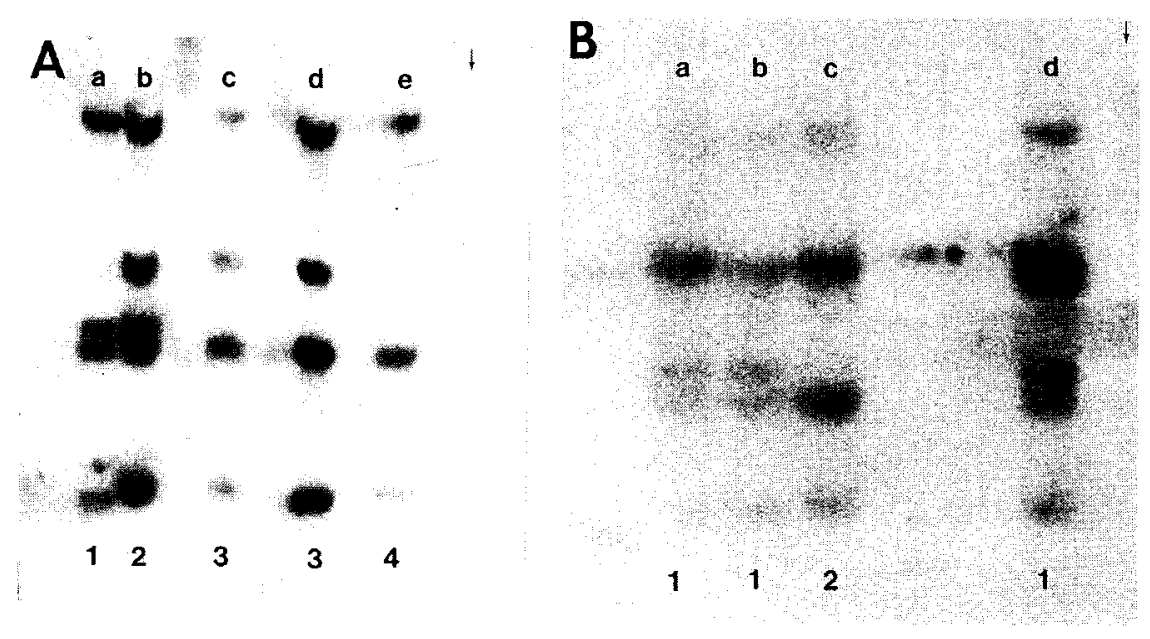

Fig. 2. RFLP patterns of somatic embryos and their maternal parents. Numerals at the bottom of each figure indicate band patterns. Arrows indicate direction of run. (A) Hybridization patterns of EcoRV digested plant DNA to probe pFP9. Lane $a=$ 'Cisco' (maternal pattern), lane $b=\mathrm{Ci}$, lane $c=$ Ci4, lane $d=$ 'Sunland' (maternal pattern), and lane e $=$ Su1. (B) Hybridization patterns of HindIII digested DNA to probe pFP10. Lanes a and $d=$ 'Cisco', lane $b=\mathrm{Ci} 4$, and lane $\mathrm{c}=\mathrm{Ci} 3$.

Table 1. Band patterns of walnut somatic embryos and their matemal parents.

\begin{tabular}{|c|c|c|c|}
\hline \multirow[b]{2}{*}{ Genotype $^{y}$} & \multicolumn{2}{|c|}{ RFLP locus ${ }^{2}$} & \multirow[b]{2}{*}{$\begin{array}{c}\text { Isozyme }^{\mathrm{w}} \\
(\mathrm{PGM})\end{array}$} \\
\hline & $\begin{array}{c}\mathrm{pFP9/} \\
\text { EcoRV }\end{array}$ & $\begin{array}{l}\text { pFP10/ } \\
\text { HindIII }\end{array}$ & \\
\hline $\begin{array}{l}\text { Cisco } \\
\mathrm{Ci} 1 \\
\mathrm{Ci} 2 \\
\mathrm{Ci} 3 \\
\mathrm{Ci} 4\end{array}$ & $\begin{array}{c}1 \\
\mathrm{NT}^{\mathrm{v}} \\
2 \\
-- \\
3\end{array}$ & \begin{tabular}{c}
1 \\
$\cdots-{ }^{u}$ \\
\hdashline- \\
1
\end{tabular} & $\begin{array}{l}2 \\
6 \\
2 \\
2 \\
2\end{array}$ \\
\hline $\begin{array}{l}\text { Sunland } \\
\text { Su1 } \\
\text { Su2 } \\
\text { Su3 }\end{array}$ & $\begin{array}{l}3 \\
4 \\
\ldots- \\
---\end{array}$ & $\begin{array}{l}-- \\
\cdots \\
\cdots \\
--\end{array}$ & $\begin{array}{l}6 \\
6 \\
6 \\
6\end{array}$ \\
\hline
\end{tabular}

${ }^{2}$ RFLP patterns $1-4$ refer to band patterns as shown in Fig. 2.

${ }^{{ }^{\prime}} \mathrm{Ci}=$ 'Cisco' somatic embryos. Su = 'Sunland' somatic embryos.

${ }^{x}$ Walnut DNA probe-restriction enzyme combinations.

wZymotypes as shown in Arulsekar et al., 1986. "Not tested.

"Missing data.

outside of the ovule strongly suggests that it was initiated from a somatic tissue of maternal type.

Four putatively unfertilized 2-cm 'Cisco' fruits, all in one bag, that had not abscised and continued to grow normally for 8 weeks postanthesis were suspected to be apomictic. These were aseptically opened and their embryos were cultured immediately. One embryo was cultured on DKW-C basal medium solidified with $0.5 \%$ Seaplaque agarose and supplemented with one of the following addenda: 1) $1.7 \mathrm{mM}$ glutamine, $0.05 \mu \mathrm{M} \mathrm{TDZ}$, $5.7 \mu \mathrm{M}$ IAA, $10 \mu \mathrm{M}$ silver nitrate, Cefotaxime (500 mg.liter $\left.{ }^{-1}\right)$; 2) $856 \mu \mathrm{M}$ glutamine, $0.44 \mu \mathrm{M}$ BAP, $0.93 \mu \mathrm{m}$ kinetin and $5.0 \mu \mathrm{M}$ IBA, 3) $1.7 \mathrm{~mm}$ glutamine, $0.9 \mu \mathrm{m}$ zeatin, $5.7 \mu \mathrm{m} \mathrm{IAA}, 10 \mu \mathrm{m}$ silver nitrate; or 4) 1.7 $\mathrm{mM}$ glutamine, $5.7 \mu \mathrm{M}$ IAA, $10 \mu \mathrm{M}$ silver nitrate. The embryos on media 1 and 2 produced somatic embryos that continued to multiply when transferred after 3 weeks to DKW-C basal medium. The other two em- bryos developed somatic embryos only when later subcultured to DKW-C basal medium, and these eventually callused.

Isozyme procedures. Tissues from the somatic embryos were analyzed for phosphoglucomutase (PGM; EC 2.7.5.1) and esterase (EST; EC 3.1.1.2) isozyme electrophoresis patterns to determine whether they originated from maternal or zygotic tissues. Esterase isozymes were not clearly resolved and were not used for determination of parentage. 'Sunland' and 'Cisco' leaves were used to provide standard isozyme patterns for the maternal genotypes. Extraction, electrophoresis, and staining protocols are described in Arulsekar and Parfitt (1986). Reference patterns and inheritance for PGM are presented in Arulsekar et al. (1986).

RFLP procedures. DNA was isolated from 1 to $3 \mathrm{~g}$ of somatic embryo or callus tissue using the minipreparation method of Dellaporta et al. (1983). Leaves of 'Sunland' or 'Cisco' were used for isolation of maternal DNA standards. After a 1-h RNAse digestion with $10 \mu \mathrm{g}$ RNAse/ml (Sigma, St. Louis) at $37 \mathrm{C}$, extraction with $24: 1$ chloroform/ $10-\mu \mathrm{g}$ samples of DNA were digested with 40 units of EcoRV or HindIII (Pharmacia, Piscataway, NJ.) for $5 \mathrm{~h}$, electrophoresed for $20 \mathrm{~h}$ at $1 \mathrm{~V} / \mathrm{cm}$ in a $1 \times \mathrm{TAE} 0.8 \%$ agarose gel containing $0.5 \mu \mathrm{g}$ ethidium bromide/ml and transferred onto Schleicher and Schuell (S\&S, Keene, N.H.) Nytran membranes. Prehybridizations and hybridizations were done in heat-sealed bags at $42 \mathrm{C}$ with $50 \%$ formamide according to $\mathrm{S} \& \mathrm{~S}$ recommendations. Walnut DNA probes pFP9 and pFP10, cloned in the vector pUC18, were radiolabelled with ${ }^{32} \mathrm{p}$-dCTP by a random priming reaction. Hybridizations were performed from 24 to $48 \mathrm{~h}$. Membranes were washed twice for $15 \mathrm{~min}$ with $2 \times \mathrm{SSC}(0.3$ $\mathrm{M} \mathrm{NaCl}, 0.03 \mathrm{M} \mathrm{Na}$ citrate) at $25 \mathrm{C}, 0.1 \%$ sodium dodecyl sulfate (SDS), followed by two 15 -min $1 \times$ SSC, $0.5 \%$ SDS washes at $40 \mathrm{C}$, and a $0.5 \times \mathrm{SSC}, 0.5 \%$ SDS wash for isoamyl alcohol, and ethanol precipitation,
$30 \mathrm{~min}$ at $65 \mathrm{C}$. The membranes were exposed to X-ray film and intensifying screens for 3 days at - 70C. Probes pFP9 and pFP10 produced reliable hybridization and were sufficient to differentiate the somatic embryos from parental material with the hybridization patterns observed.

Analysis of embryo origin. PGM isozyme analysis suggested that 'Sunland' somatic embryos from the bagged unfertilized ovules as well as the torpedo stage embryo (Su1$\mathrm{Su} 3$ ) originated from material tissue (Fig. 1A; Table 1). PGM analysis of somatic embryos from fertilized unbagged 'Sunland' ovules indicated that only one embryo was definitely of nonmaternal genotype (Fig. 1B). PGM isozyme analysis was not sufficient to indicate the parentage of the embryos. Additional testing, RFLP analysis, was therefore required to determine the exact origin of the somatic embryos. RFLP analysis of bagged ovules revealed that the torpedo embryo (Su1) was of zygotic origin due to observed differences between Sul and maternal pFP9/EcoRV fragments (Fig. 2A; Table 1). Missing data entries, such as those for Su2 and Su3, occurred because insufficient DNA was isolated from the embryos. Although adequate amounts of DNA were obtained by using the DNA isolation procedure reported above, some embryos had little or no tissue mass left to sample after failed DNA isolation attempts using other techniques. Consequently, the origin of embryos $\mathrm{Su} 2$ and $\mathrm{Su} 3$ could not be determined. Embryos from bagged fruits probably resulted from either pollination before bagging, pollen that remained viable inside the bag until flowers became receptive, or poorly sealed bags.

PGM isozyme comparisons of 'Cisco' somatic embryos from the suspected apomictic ovules with maternal tissue disclosed that Ci1 originated from open-pollinated zygotic tissue rather than maternal tissue (Fig. 1A; Table 1). RFLP analysis of DNA from the other three clones with pFP9/EcoRV and pFP10/ Hind 111 probe-enzyme combinations revealed that they also originated from zygotic (nonmaternal) tissue (Fig. $2 \mathrm{~A}$ and B; Table 1).

Value of molecular markers for analysis of embryo origin. The use of isozyme and RFLP analyses proved valuable in detecting the tissue from which the somatic embryos originated. RFLP analysis, using two walnut DNA probes $\times$ restriction enzyme combinations, and PGM isozyme analysis demonstrated that somatic embryos originated from zygotic rather than maternal tissue. To our knowledge, this is the first reported use of RFLP analysis to assess possible apomixis in walnuts. DNA fingerprinting with minisatellite probes (Dallas, 1988) may also prove useful for early screening as well as confirming the origin of the somatic embryos. However, no significant polymorphisms were identified in our laboratory among walnut cultivars during preliminary studies with the M13 minisatellite probe (Rogstad et al., 1988).

A prerequisite for the use of biochemical genetic markers is the presence of markers 
that are polymorphic in the walnut parents or in the general pool of walnut pollinators. For those markers that are heterozygous at a single locus, the probability of identifying a nonmaternal genotype is 0.5 (represented by homozygote genotypes) if selfing or crossing to males with the same alleles occurs. Nonmaternal genotypes will also be detected from the presence of nonmaternal alleles, resulting in detection of a nonmaternal genotype frequency from 0.5 to 1.0. The presence of a maternal genotype at the locus does not imply that the embryo is of apomictic origin, since heterozygotes can also occur from fertilization events. Therefore, when discussing probability of apomixis we can only establish a maximum value. The actual frequency of apomixis may be much less. However, given analysis at several loci with an appropriate selection of alleles in potential male parents, it is often possible to eliminate most or all of the embryos as possible apomicts. This was true for the present study. The maximum probability of apomixis is: $P=$ $(0.5)^{k}$, where $P=$ probability of having the maternal genotype and $\mathrm{k}=$ number of heterozygous loci tested. A $95 \%$ level of confidence that an offspring is identical to its maternal parent could be established by testing five heterozygous markers $(P=0.031)$. For walnuts, $\approx 20 \%$ of our probe/enzyme combinations show heterozygosity. Thus, up to 25 markers could be required to show that apomixis had occurred with $>95 \%$ confidence. However, as seen in the present study, relatively few markers may eliminate the possibility of apomixis within a given population of embryos. For situations where the possibility of selfing can be dismissed and only nonmaternal alleles are present in the pollinator population, only one marker is needed to test for apomixis. A second marker could be used to confirm the results.

This study illustrates the direct use of molecular genetic markers at an applied level to facilitate plant improvement programs. In addition to evaluation of somatic embryos, these markers may be used to evaluate the products of protoplast fusion experiments or progeny from crosses at the seed or seedling stage. They provide unambiguous results in a very short time.

\section{Literature Cited}

Arulsekar, S. and D.E. Parfitt. 1986. Isozyme analysis procedures for stone fruits, almond, grape, walnut, pistachio, and fig. HortScience 21:928-932.

Arulsekar, S., G.H. McGranahan, and D.E. Parfitt. 1986. Inheritance of phosphoglucomutase and esterase isozymes in Persian walnut. J. Hered. 77:220-221.

Castle, A.J., P.A. Horgen, and J.B. Anderson. 1987. Restriction fragment length polymorphisms in the mushrooms Agaricus brunnescens and Agaricus bitorquis. Applied Environ. Microbiol. 53:816-822.

Dallas, J.F. 1988. Detection of DNA "fingerprints" of cultivated rice by hybridization with a human minisatellite DNA probe, Proc. Natl. Acad. Sci. USA 85:6831-6835.

Dellaporta, S.L., J. Wood, and J.B. Hicks. 1983. A plant DNA minipreparation: Version II. Plant Mol. Biol. Rptr. 1:19-21.
McGranahan, G.H., C.A. Leslie, S.L. Uratsu, L.A. Martin, and A.M. Dandekar. 1988. Agrobacterium-mediated transformation of walnut somatic embryos and regeneration of transgenic plants. Biotechnol. 6:800-804.

McGranahan, G.H., C.A. Leslie, S.L. Uratsu, and A.M. Dandekar. 1990. Improved efficiency of the walnut somatic embryo gene transfer system. Plant Cell Rpt. 8:512-516.

Rogstad, S.H., J.C. Patton, and B.A. Schaal. 1988. M13 repeat probe detects DNA minisatellitelike sequences in gymnosperms and angiosperms. Proc. Natl. Acad. Sci. USA 85:91769178.

Sauer, D.B. and R. Burroughs. 1986. Disinfection of surfaces with sodium hypochlorite. Phy topathology 76:745-749.
Tulecke, W. and G. McGranahan. 1985. Somatic embryogenesis and plant regeneration from cotyledons of walnut, Juglans regia L. Plant Sci. 40:57-63.

Tulecke, W., G. McGranahan, and H. Ahmadi. 1988. Regeneration by somatic embryogenesis of triploid plants from endosperm of walnut, $J$. regia L. cv. Manregian. Plant Cell Rpt. 7:301304.

Woodworth, R.H. 1930. Meiosis of microsporogenesis in the Juglandaceae. Amer. J. Bot. 17:863-869.

Zamir, D., S.D. Tanksley, and R.A. Jones. 1981. Genetic analysis of the origin of plants regenerated from anther tissues of Lycopersicon esculentum. Plant Sci. Let. 21:223-227.

HoRTSCIENCE 27(1):63-65. 1992.

\title{
Somatic Embryogenesis in Carnation
}

\author{
Les Frey, Yehoshua Saranga, and Jules Janick \\ Purdue University, 1165 Horticulture Building, West Lafayette, \\ IN 47907-1165
}

\section{Additional index words. Dianthus caryophyllus, histology}

Abstract. Somatic embryogenesis was induced from internodal callus of 'Scania', 'Improved White Sim', and 'Sandra' carnation (Dianthus caryophyllus L.). The optimum protocol for the induction of somatic embryogenesis included initiation of callus in liquid basal Murashige and Skoog medium supplemented with 3.0 $\mu_{M}$ 2,4-D followed by transfer to liquid basal medium lacking 2,4-D for embryo development. Somatic embryos originated from single cells and early embryonic development proceeded conventionally (i.e., via globular, heart-shaped, and torpedo stages), but clearly developed apical or root meristems were not always formed. A few embryos developed into seedlings and were acclimatized to ex vitro conditions. Chemical name used: 2,4-dichlorophenoxyacetic acid $(2,4-D)$.

Somatic embryogenesis induced from mature somatic tissue is a desirable means of rapid vegetative propagation (Ammirato, 1983; Janick et al., 1989). This study was undertaken to determine the feasibility of inducing somatic embryos from sporophytic tissue of carnation, a species, to our knowledge, for which somatic embryogenesis has not been reported previously,

Stock plants of 'Scania', 'Improved White Sim', and 'Sandra' carnation were maintained in a greenhouse at $16 \mathrm{C}$ (days) and 10C (nights) with supplemental light from incandescent bulbs to interrupt winter nights.

In a preliminary study, young internodal tissues from 'Improved White Sim' were disinfested for 30 set in $80 \%(\mathrm{v} / \mathrm{v})$ ethanol and surface sterilized for $30 \mathrm{~min}$ in a $0.5 \%$ $(\mathrm{v} / \mathrm{v})$ solution of $\mathrm{NaOCl}[10 \%$ laundry bleach $(\mathrm{v} / \mathrm{v})]$ containing a few drops of Tween 20. Tissues were then rinsed four to five times with sterile distilled water, cut into explants

Received for publication 7 Feb. 1991. Accented for publication 15 July 1991. Journal paper-no. 12,817 of the Purdue Univ. Agriculture Experiment Station. The cost of publishing this paper was defrayed in part by the payment of page charges. Under postal regulations, this paper therefore must be hereby marked advertisement solely to indicate this fact. $\approx 8 \mathrm{~mm}$ in length, and cultured on callus induction medium (CIM) consisting of Murashige and Skoog (1962) salts, MS vitamins, $87.6 \mu \mathrm{m}$ sucrose, and $1.0 \mathrm{~g}$ casein hydrolysate/liter. Semisolid media contained $8 \mathrm{~g}$ agar/liter (Sigma, St. Louis). Various plant growth regulators (as listed below) were added, $\mathrm{pH}$ adjusted to 5.8, and the media were autoclaved for $20 \mathrm{~min}$ at $120 \mathrm{kPa}$. The

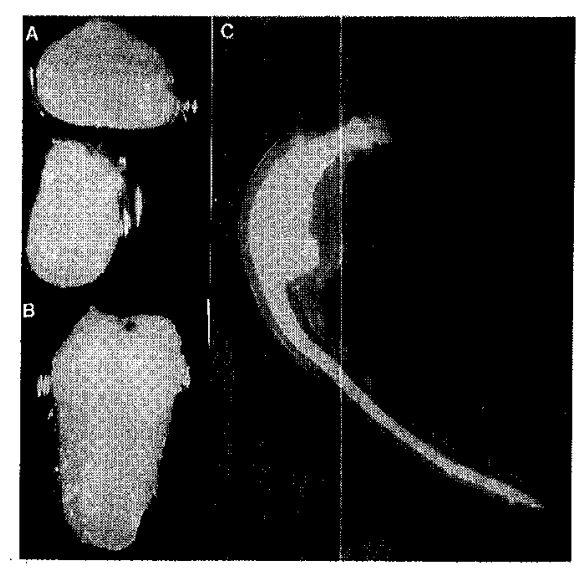

Fig. 1. Somatic embryos of 'Improved White Sim' carnation: (A) globular stage; (B) heart-shaped stage; (C) germinating embryo with poorly differentiated cotyledons. 